Document downloaded from:

http://hdl.handle.net/10251/153456

This paper must be cited as:

Benajes, J.; Novella Rosa, R.; Pastor Enguídanos, JM.; Hernández-López, A.; Duverger, T. (2017). A computational analysis of the impact of bore-to-stroke ratio on emissions and efficiency of a HSDI engine. Applied Energy. 205:903-910.

https://doi.org/10.1016/j.apenergy.2017.08.023

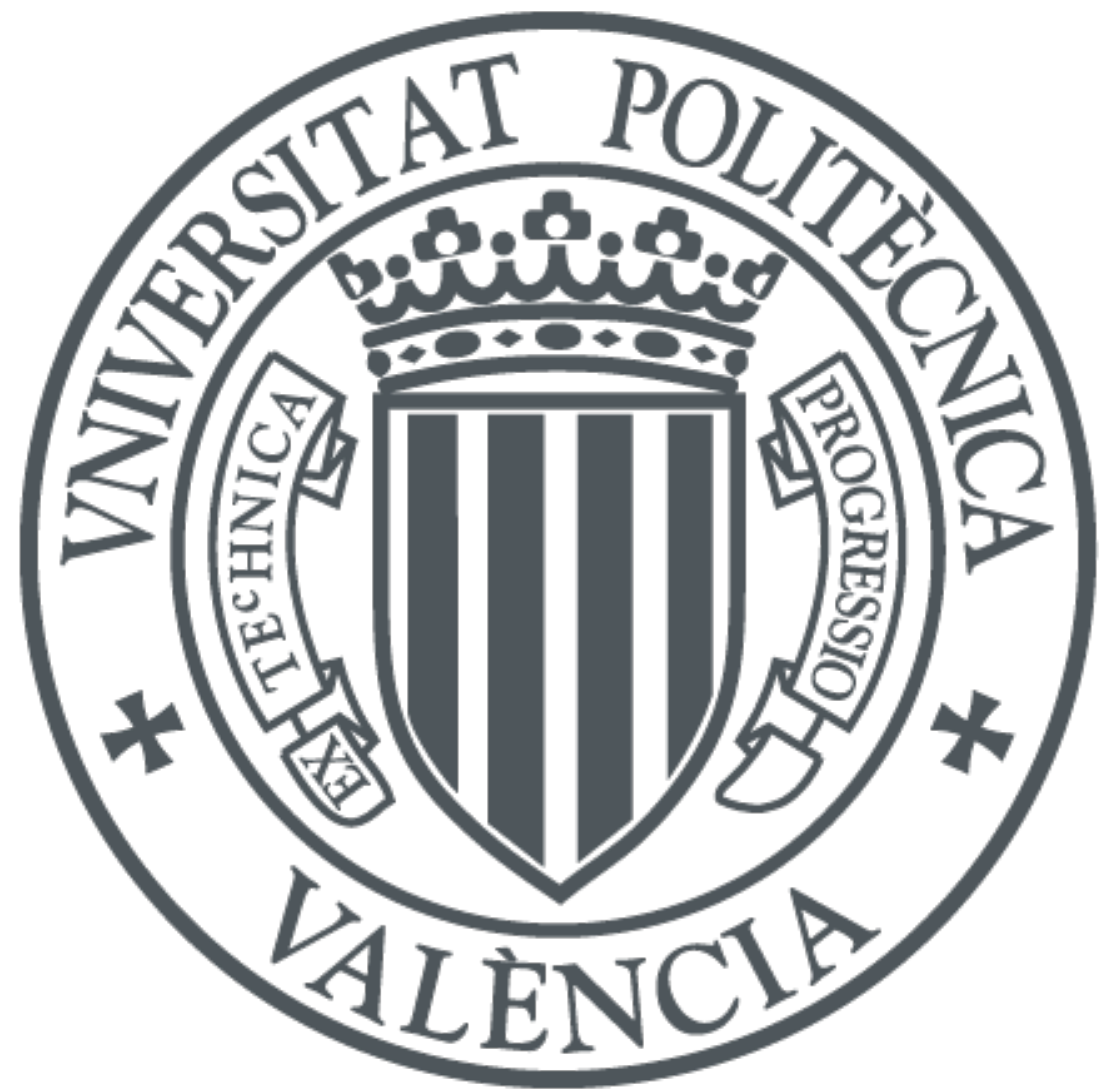

The final publication is available at

https://doi.org/10.1016/j.apenergy.2017.08.023

Copyright Elsevier

Additional Information 


\title{
A computational analysis of the impact of bore-to- stroke ratio on emissions and efficiency of a HSDI engine
}

\author{
J. Benajes ${ }^{1}$, R. Novella ${ }^{1}$, J.M. Pastor ${ }^{1}$, A. Hernández-López ${ }^{1}$, T. Duverger ${ }^{2}$ \\ ${ }^{1} \mathrm{CMT}$ - Motores Térmicos \\ Universitat Politècnica de València \\ Camino de Vera s $n$ \\ 46022 Valencia (Spain) \\ ${ }^{2}$ Combustion and Fuel Supply Functions \\ PSA Groupe \\ 18 rue des Fauvelles BP16 \\ 92256 La Garenne Colombes Cedex (France)
}

\section{Abstract}

Research on combustion systems for Internal Combustion Engines (ICE) is guided by the necessity of improving engine efficiency while achieving the pollutant regulations. In this framework, this study identifies and describes the effect of the bore-to-stroke ratio (B/S) on the combustion system performance and emissions by means of computational fluid dynamics (CFD).

The study is applied to a 4-cylinder 4-stroke High Speed Direct Injection (HSDI) CI engine. It is divided in two parts, the first part is focused on one operating point and presents a detailed description of the main effects of different B/S ratios configurations, and the second part compares the results with different engine operating conditions. For both parts the air management, injection settings and compression ratio were kept constant in order to isolate the impact of the $\mathrm{B} / \mathrm{S}$ ratio.

The results confirmed that the indicated thermal efficiency was increased for lower B/S ratio because of the combustion chamber surface area decrease and faster combustion. Regarding the emissions, NOx and soot presented a strong and opposed dependence on $\mathrm{B} / \mathrm{S}$ ratio generated mostly due to enhanced air-fuel mixing for lower B/S ratio. Finally, those trends were proven to be independent from the operating condition, giving the study a more general value.

Keywords:

Diesel Engine, CFD model, Bore-to-Stroke ratio, Engine Efficiency, Emissions control 


\section{Introduction}

Optimizing the Internal Combustion Engines (ICE) for transport applications is a major research topic due to the needs of fulfilling the current and future pollutant emission regulations. For that reason, the investigation in this field has been driven by the need of decreasing pollutants and overcome mechanical limitations. Nowadays, especially for Compression Ignition (CI) engines, keeping their fuel consumption levels competitive compared to the Spark Ignition (SI) engines to control $\mathrm{CO}_{2}$ emissions have gained importance and some aspects, such as heat transfer, have become even more relevant in the current framework of ICE research.

Historically, the optimization strategies in compression ignition (CI) engines have been focused on improving air management [1], injection settings [2], nozzle definition or piston bowl geometry $[3,4,5]$. This trend continues due to the increasingly stringent emission standards and further CI engine investigation focuses on including dual fuel strategies [6] or fuel blends coupled with injection settings optimization [7]. However, the basic geometric architecture, such as bore-to-stroke, tend to be kept unchanged or modified within a quite limited range for small and some medium sized diesel engines. This fact has generated a recent interest since a fine tuning of $\mathrm{B} / \mathrm{S}$ ratio has potential to improve heat transfer, mixing time or friction [8], resulting in an overall improvement in engine efficiency or power density. It is interesting, therefore, to re-examine those scaling relationships traditionally used to describe engine performance, and assess their impact on 4-cylinder 4-stroke High Speed Direct Injection (HSDI) CI engine.

Experimental optimization is a well-known method due to the simplicity of adjusting air management, injection setting or fuel composition aiming for an improved combustion process. Therefore, in the past years a lot of the research works focused on combustion system optimization, have been performed experimentally $[9,10,11]$. However, when engine hardware, such as the combustion chamber or the injector nozzle definition, is involved in the optimization tasks, the process is costly in terms of time and resources since it involves manufacturing and assembling parts, together with weeks or even months of intensive testing. For that reason, limited experimental research has been reported in the literature discussing the optimum bore-to-stroke $(B / S)$ ratio for engines equipped with state-of-the-art air management and injection systems, and also restricted to the current emissions constraints. Kermani et al. [12] performed an experimental study of the influence of the $\mathrm{B} / \mathrm{S}$ ratio on fuel consumption, performance and emissions on a light-duty Diesel engine. Experiments proved how higher B/S ratios increase heat transfer losses, due to the higher combustion chamber area-to-volume ratio at TDC, resulting in a decrease of the indicated mean effective pressure (IMEP). Additionally, it was also shown that decreasing B/S ratios increase the piston swept surface resulting in an increase of friction losses. The study converges to an optimum B/S ratio range of 0.9-0.95, being 0.85 the smallest B/S ratio evaluated. Also from an experimental study, Lavoisier et al. [13] pointed out that higher $\mathrm{B} / \mathrm{S}$ ratio will allow wider bowls that improve combustion process at high speed and load. This could be counteracted by the less favorable $k$-factor (ratio of 
bowl volume to total volume of the combustion chamber at TDC), which limits the air utilization. In this study was found an optimal B/S ratio close to 0.93 , taking into account maximum rated power, fuel consumption and pollutants.

In terms of engine efficiency, the $\mathrm{B} / \mathrm{S}$ ratio has an impact on both heat losses to the walls and friction losses [16], so a balance has to be found between those two counteracting effects. Several studies have been performed investigating the mechanical losses, Payri et al [17] showed that the mechanical losses represents around 4 to $10 \%$ of the total fuel energy injected. Subsequently, those authors [18] further developed their research, proving that the friction between the piston and the liner is responsible for $50 \%$ of the total mechanical losses, so that the piston friction results in 2 to $5 \%$ of the total energy.

Recently, computational modeling is gaining reliability in predicting combustion and pollutants by using properly calibrated and validated models, not only because the predicted results have a high accuracy but also because it offers an in depth analysis that cannot be performed experimentally with the current measurement techniques. Then, computational modeling has been used to further study the effect of B/S ratio in CI engines, mostly for predesign purposes. During this stage of the engine design, $1 \mathrm{D}$ models are dominant since they offer a quick and robust prediction of the whole engine behavior. However, these models tend to excessively simplify the combustion process or even use correlations to simulate its behavior. Vassallo et al. [14] carried out an investigation of the impact of $\mathrm{B} / \mathrm{S}$ ratio also on a light-duty engine. The results were obtained by employing a 1D approach based on Design of Experiments (DOE) methodology. They show that $\mathrm{B} / \mathrm{S}$ ratio close to 1 , enables a good equilibrium between specific power rating and low-end torque thanks to the volumetric efficiency profile and the lower heat transfer by convection in the pipes. The higher volumetric efficiency for this ‘square design' and lower convection is proven to compensate its unfavorable surface-to-volume ratio. In addition, the longer stroke length of low $\mathrm{B} / \mathrm{S}$ ratio generates higher friction losses leading to better thermal efficiencies for higher $\mathrm{B} / \mathrm{S}$ ratios. The next step in the computational modeling approach, which is the use of 3D CFD simulations, have also been performed [15]. As proven, even operating with advanced combustion concepts they offer a more detailed insight on the effect of $\mathrm{B} / \mathrm{S}$ ratios and its interaction with the combustion process, in-cylinder pollutants distributions and heat transfer, allowing a better understanding of the complete problem.

From the previous discussion, due to the recent interest on the potential benefits in terms of engine efficiency attainable by redefining the optimum $\mathrm{B} / \mathrm{S}$ ratio and the high computational cost of integrating CFD modeling activities in the engine predesign stage, it is evident how the key effects of B/S ratio and how they interact are still not well understood. In this framework, the research work reported in the present paper focuses on the identification and description of the impact of the $\mathrm{B} / \mathrm{S}$ ratio on the trade-off between thermal efficiency and emissions by means of CFD modeling, this is, taking into account the detailed interaction between $\mathrm{B} / \mathrm{S}$ ratio and the combustion process. The process carried out in this paper has two main blocks, the first one focuses on one 
operating point and presents all the important effects of different B/S ratios configurations. On the second block, the previous results are compared against other operating points of the same engine.

\section{Experimental tools}

\section{Engine characteristics}

The experimental data required for the calibration and validation of the CFD model was obtained from a 4-cylinder 4-stroke High Speed Direct Injection (HSDI) CI engine, equipped with a common-rail injection system. Table 1 contains the main engine characteristic and Table 2 contains the main fuel characteristics.

Table 1 - Engine main characteristics

\begin{tabular}{lc}
\hline \multicolumn{2}{c}{ Engine data } \\
\hline Bore x stroke $[\mathrm{mm}]$ & $85 \times 88$ \\
Unitary Displacement $\left[\mathrm{cm}^{3}\right]$ & 499.36 \\
Connecting rod length $[\mathrm{mm}]$ & 145 \\
Geometric compression ratio [-] & 16.7 \\
Nozzle hole number & 7 \\
\hline
\end{tabular}

Table 2 - Fuel main characteristics

\begin{tabular}{lc}
\hline \multicolumn{2}{c}{ Engine data } \\
\hline Cetane number [-] & 46.6 \\
LHV [MJ/kg] & 42.124 \\
Stoichiometric air/fuel ratio [-] & 14.802 \\
Density [kg/m3] & 843.3 \\
Kinematic viscosity [cSt] & 2.46 \\
\hline
\end{tabular}

All the experimental results used in this paper, and additional information required to perform the study of the $\mathrm{B} / \mathrm{S}$ ratio, were provided by the engine manufacturer. Additionally, a database of injection ratio profiles for different injection settings, using the engine's injection system, was created. An in-house 0-D model code capable of reproducing any injection rate profile [1] was used to generate the needed injection rate profiles to perform the calculations. 


\section{Modeling tools}

The section below describes the experimental and theoretical tools used to carry out the research. This brief description focuses only on their most relevant characteristics.

\section{CFD model}

The StarCD code version 4.22 [25] was used to perform the CFD simulations of the engine combustion system. The axisymmetry of the combustion chamber allows to create a sector mesh comprising 157412 cells at BDC with periodic boundary conditions after performing a grid convergence study. Each case was calculated as a closed combustion cycle, this is from the intake valves closing (IVC) to the exhaust valves opening (EVO) (from 247 to $519^{\circ}$ aTDC with the TDC at $360 \mathrm{deg}$ ). The initial thermodynamic conditions and wall temperatures are obtained from the experimental cylinder pressure signal by means of the in-house combustion diagnosis code CALMEC [19,20]. The reference values used for the three operating conditions considered are shown in Table 3.

The combustion model was the ECFM-CLEH [21,22]. Concerning pollutants, $\mathrm{NO}_{\mathrm{x}}$ were calculated using a built-in NOx NORA model, which is based on the tabulation of equilibrium values of three NOx species and their relaxation times following a perturbation [23]. A sectional method based on a description of sections containing soot particles of equal volume was used for soot formation and oxidation [24].

The diesel spray was simulated by using the standard Droplet Discrete Model [25]. Spray atomization and break-up were simulated by means of the Huh-Gosman [26] and ReitzDiwakar [27] models, respectively. Diesel fuel physical properties were given by the DF1 fuel surrogate [28].

In these simulations, turbulent flow was modelled by means of the RNG k- $\varepsilon$ model [29], with wall-functions based on the model from Angelberger [30] in order to account for wall heat transfer. An implicit scheme was used for time discretization, while divergence terms used the second order Monotone Advection and Reconstruction Scheme (MARS) [25]. Velocity-pressure coupling was solved by means of a Pressure-Implicit with Splitting of Operators (PISO) algorithm [31]. 
Table 3 - In-cylinder thermodynamic conditions at IVC.

\begin{tabular}{ccccccc}
\hline Case & $\mathbf{P}_{\text {IVC }}$ & $\mathbf{m}_{\text {IVC }}$ & $\mathbf{T}_{\text {IVC }}$ & $\mathbf{Y}_{\mathbf{O} 2}$ & $\mathbf{Y}_{\mathbf{N 2}}$ & $\mathbf{Y}_{\text {RES }}$ \\
& [bar] & [g] & {$[\mathbf{K}]$} & {$[\%]$} & {$[\%]$} & {$[\%]$} \\
\hline $\begin{array}{c}\text { 1750 rpm @ } \\
\text { Full Load }\end{array}$ & 3.89 & 1.28 & 422.6 & 22.9 & 75.3 & 1.8 \\
$\begin{array}{c}\text { 2280 rpm @ } \\
\text { Part Load }\end{array}$ & 2.63 & 0.94 & 417.48 & 20.3 & 66.7 & 13 \\
$\begin{array}{c}\text { 3750 rpm @ } \\
\text { Full Load }\end{array}$ & 3.97 & 1.24 & 442.97 & 22.7 & 74.7 & 2.6 \\
\hline
\end{tabular}

The CFD model was thoroughly validated by simulating the three operating conditions under investigation, described in Table 3. The mesh used for the CFD cases was a hybrid mesh with about 160000 cells of $0.3 \mathrm{~mm}$ near the wall and $0.5 \mathrm{~mm}$ for the rest of the domain. The simulations were run with 16 processors and each simulation took between 20h and 36h depending on the operating condition. The results of the CFD model compared with the experimental data in terms of performance and pollutants, are included in Figure 1 to Figure 3 and Table 4.

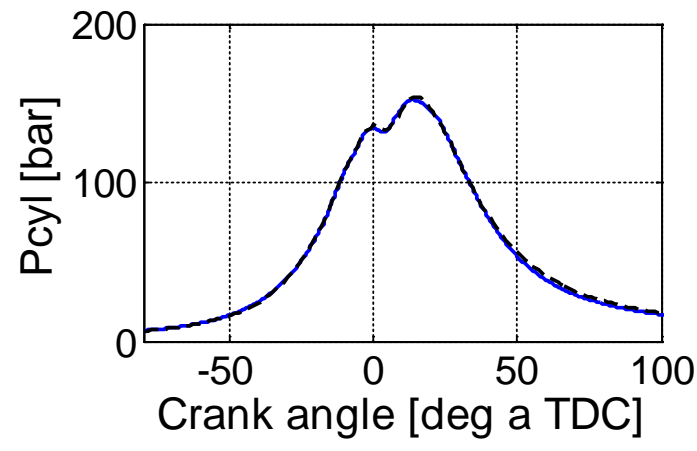

(a)

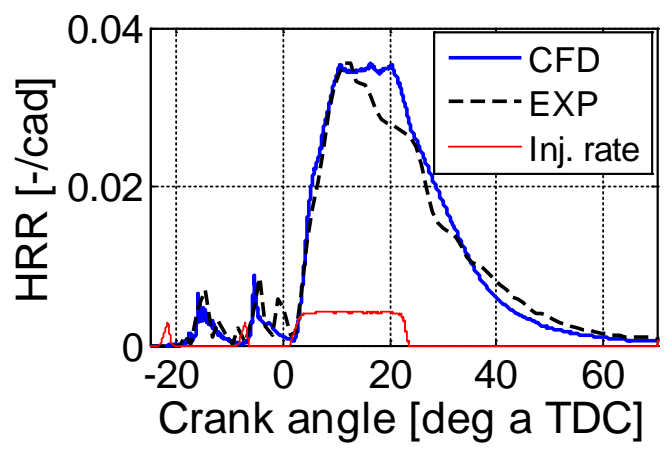

(b)

Figure 1 - Experimental vs CFD results at 1750 rpm@ Full Load. In-cylinder pressure (a) and normalized heat release rate (b)

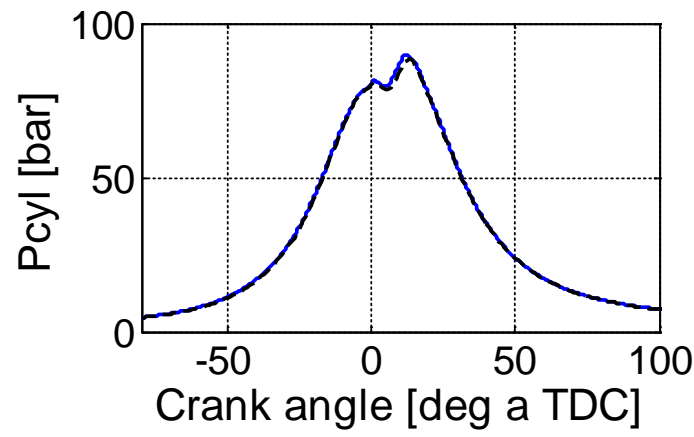

(a)

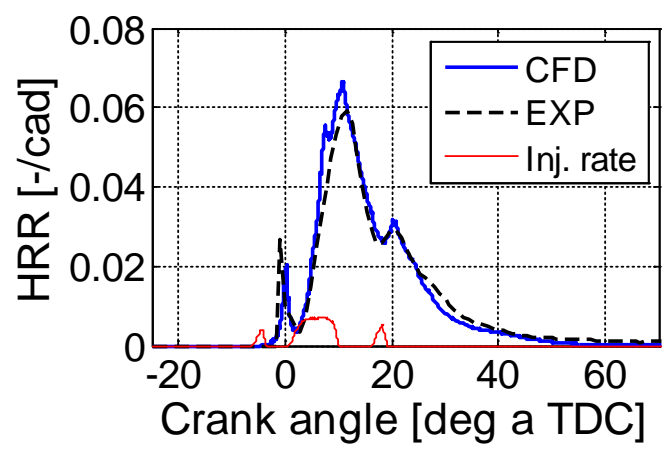

(b)

Figure 2 - Experimental vs CFD results at 2280 rpm @ Part Load. In-cylinder pressure (a) and normalized heat release rate (b) 


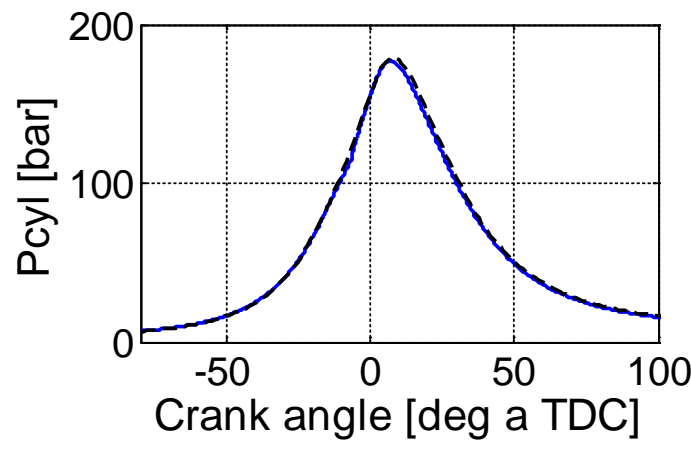

(a)

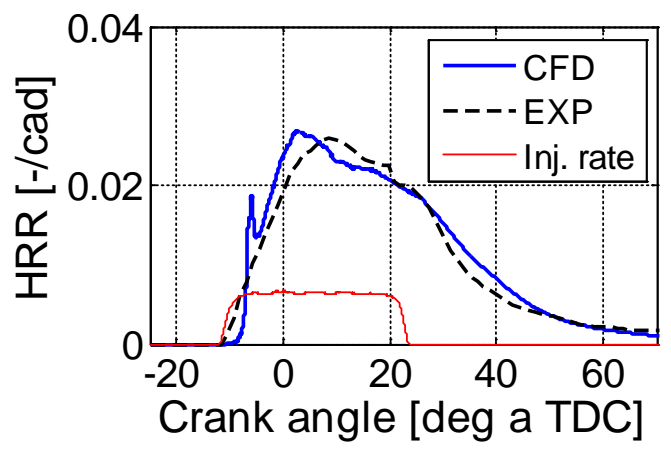

(b)

Figure 3 - Experimental vs CFD results at 3750 rpm@ Full Load. In-cylinder pressure (a) and normalized heat release rate (b)

Table 4 - Experimental vs CFD pollutants emissions and IMEP results for the engine.

\begin{tabular}{ccccc}
\hline \multicolumn{1}{c}{ Case } & & $\begin{array}{c}\text { IMEP } \\
\text { [bar] }\end{array}$ & $\begin{array}{c}\text { SOOT } \\
\text { [g/h] }\end{array}$ & $\begin{array}{c}\text { NOx } \\
\text { [g/h] }\end{array}$ \\
\hline 1750 rpm @ & EXP & 25.96 & 7.23 & 480.0 \\
Full-load & CFD & 25.37 & 7.3 & 739.1 \\
2280 rpm @ & EXP & 8.7 & 0.54 & 77.2 \\
Part-load & CFD & 9.02 & 1.04 & 63.6 \\
3750 rpm @ & EXP & 23.32 & 17.92 & 991 \\
Full-load & CFD & 22.7 & 17.51 & 1076.5 \\
\hline
\end{tabular}

Those figures show a fair agreement in terms of performance (IMEP) and combustion characteristics (HRR). In addition, the final soot levels were close to experimental data after calibrating the model constants on the 3750 rpm @ Full Load operating condition. An over-prediction of $\mathrm{NO}_{\mathrm{x}}$ values is observed for the 1750 rpm @Full-load load condition, probably related with the fast reduction in HRR during the main injection that was not able to be captured properly by the CFD model compared to experimental data. Nevertheless, the quality of the CFD model was considered as suitable for carrying out the optimization activities.

\section{Methodology}

This section shows how the bore-to-stroke variations were done and the assumptions that were taken for performing the CFD calculations.

An important aspect of the present study is to isolate as much as possible the effect of the $\mathrm{B} / \mathrm{S}$ ratio. In this case, when changing this parameter, the boundary conditions and initialization setup were all kept constant and only the geometry was modified, so injection settings, volumetric compression ratio and displacement were kept constant at 
the reference value. The study was focused on four B/S ratio levels, ranging from 0.8 to 1.1 , using the original engine value, $\mathrm{B} / \mathrm{S}=0.966$ as the reference value.

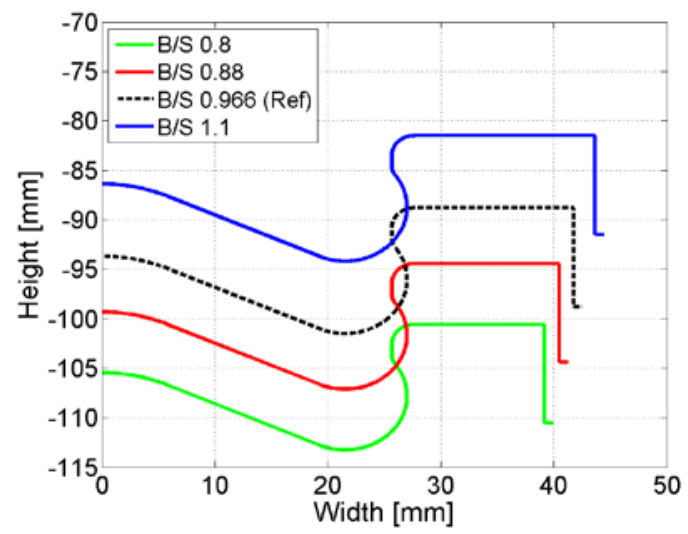

Figure 4 - Geometries with different B/S values.

As seen in Figure 4, the shape of the piston bowl was kept unchanged for all the cases, in order to isolate B/S effects. In order to keep the engine compression ratio, a compensation volume, which accounts for valve recesses and other not resolved cylinder head geometric details, was generated in the cylinder head following the same approach as found in the literature [32]. However, the squish gap between the cylinder head and the flat top of the piston (from just before the end of bowl to the full piston bore) was kept constant for all $\mathrm{B} / \mathrm{S}$ ratios, and only this compensation volume was adjusted to keep constant the compression ratio for all cases. As shown in Table 5, the connecting rod was modified in order to keep as constant as possible the evolution of the volume during the combustion process.

Table 5 - Geometric characteristics for each $\mathrm{B} / \mathrm{S}$ ratio case.

\begin{tabular}{ccccc}
\hline B/S ratio & 0.8 & 0.88 & 0.966 & 1.1 \\
Bore [mm] & 79.8 & 82.4 & 85 & 88.8 \\
Stroke [mm] & 99.8 & 93.6 & 88 & 80.7 \\
Connecting Rod & 164.4 & 154.3 & 145 & 133 \\
$\begin{array}{c}\text { length [mm] } \\
\text { k-factor [-] }\end{array}$ & 0.88 & 0.87 & 0.86 & 0.845 \\
\hline
\end{tabular}

It has to be pointed out that the air-loop system has not been simulated, then the impact of B/S ratio on open-loop cycle was not directly assessed. However some aspects about the hypothesis of unchanged initial conditions have been considered. As a method to identify if volumetric efficiency is significantly affected by the mandatory reduction of inlet valves diameter, the average Mach number of the air flowing across the inlet valves during the intake stroke was calculated following the classical Taylor formulation, and proven to be lower than 0.5 in the worst case (max rpm and min B/S ratio), what is lower than the limit for Mach number equal to 0.5 where compressibility effects arise [16]. Regarding the rest gas contents, it has been estimated that represents 4 to $6 \%$ of total 
trapped mass for the operating conditions evaluated, and then the variations due to $\mathrm{B} / \mathrm{S}$ ratio has been neglected. In addition, as the air-loop system was not modeled, no pumping work losses were taken into account. The effect of decreasing B/S ratio over the pumping work and then over specific parameters is expected to be negative and non-negligible due to the extended sonic flow period during the blow-down through smaller exhaust valves, but the detailed evaluation of the specific parameters is beyond the scope of the present research work.

Additionally, some friction loses estimations were performed. Following Miles and Andersson [8], friction losses scale inversely with $\mathrm{B} / \mathrm{S}$. In this case the $\mathrm{B} / \mathrm{S}$ ratio is modified from 0.8 to 1.1 which represents a maximum variation of $28 \%$ of the total friction loses, this is, 0.5 to $1.25 \%$ of the total injected energy [33]. However, as the analysis of specific parameters is out of the scope of the present investigation, the impact of this variation was not discussed.

\section{Results and discussion}

A detailed study was carried out with the aim of investigating the impact of the B/S ratio on engine performance and emissions. Firstly, a detailed analysis for the high-speed/load point (3750 rpm @ Full-load) has been performed. After that the results for the other two operating conditions are presented.

\subsection{B/S impact at high-speed/load}

Focusing on the combustion process, Figure 5 shows accumulated heat release law (HRL) for all the $\mathrm{B} / \mathrm{S}$ ratios considered and the differences relative to the reference $\mathrm{B} / \mathrm{S}$. It can be seen how reducing $\mathrm{B} / \mathrm{S}$ ratio produces an increase in accumulated heat release up to around 80 cad after the start of combustion, when more than of $90 \%$ of the total HRL has been achieved. However, this advantage is later recovered by larger B/S ratios achieving nearly the same value of HRL at the end of the combustion.

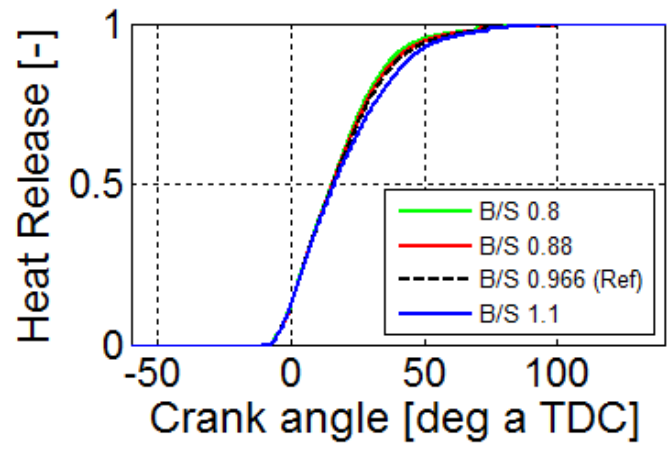

(a)

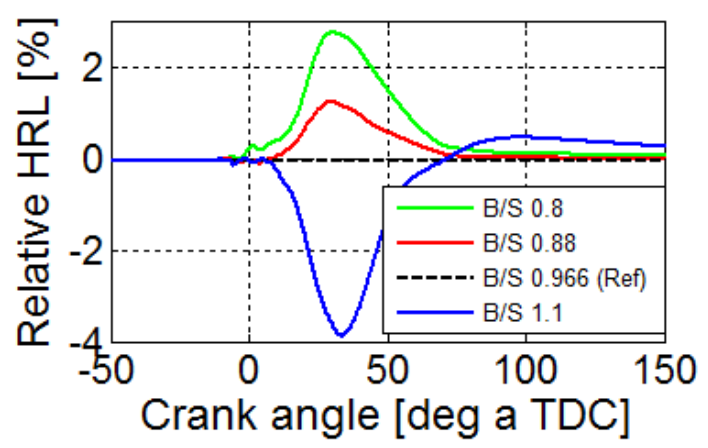

(b)

Figure 5 - Normalized HRL (a) and HRL differences relative to the reference B/S case (b) at highspeed/load operating point. 
In terms of combustion duration, defined here as the difference between the crank angles corresponding the $90 \%$ and $10 \%$ of total HRL (named as CA90 and CA10 respectively), Figure 6 clearly indicates how is reduced when B/S is decreased.

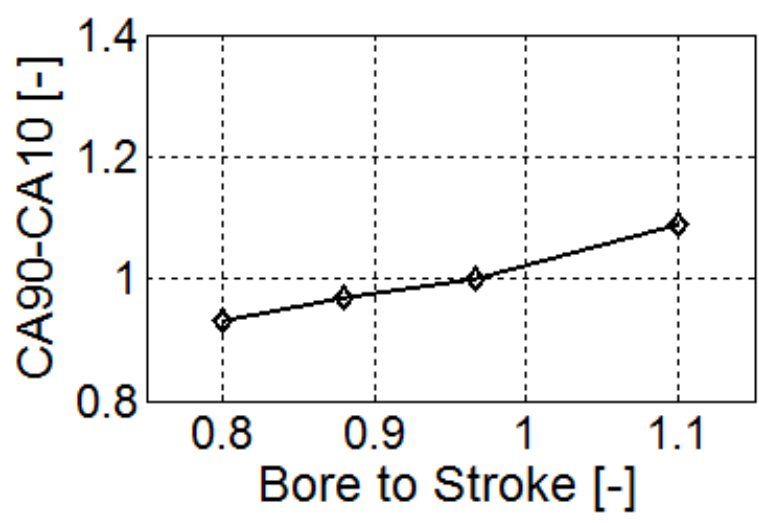

Figure 6 - Combustion duration (CA90-CA10) normalized at high-speed/load operating point.

Faster combustion for lower B/S ratios is due to improved air/fuel mixing, as indicated in Figure 7, where the amount of fuel mass over stoichiometric conditions is shown (only extremes plotted to facilitate understanding). These differences in air/fuel mixing cannot be attributed to different piston bowl characteristics such as in [13], but to the different squish dimensions and $k$-factor (see Table 5) which results in modified in-cylinder spray and air flow interaction.

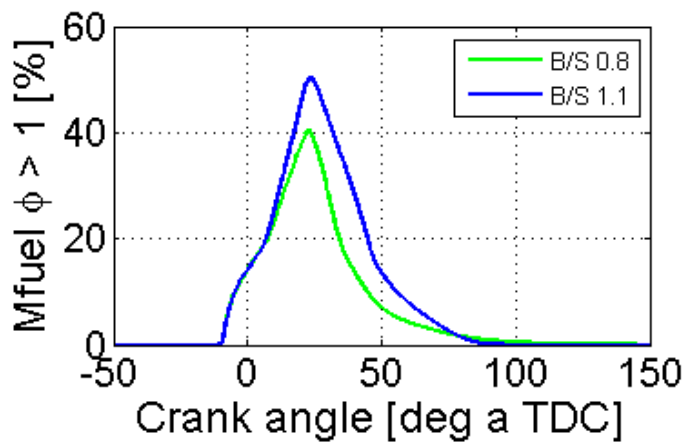

Figure 7 - Percentage of fuel mass with equivalence ratio over stoichiometry at high-speed/load operating point.

Concerning heat losses, Figure 8 (a) shows the total heat transfer (HT) where it can be seen how lower $\mathrm{B} / \mathrm{S}$ ratios results in lower heat transfer. Thus lower $\mathrm{B} / \mathrm{S}$ ratio have faster mixing and combustion and have lower heat transfer values, leading to higher indicated efficiency, as shown in Figure 8 (b). 


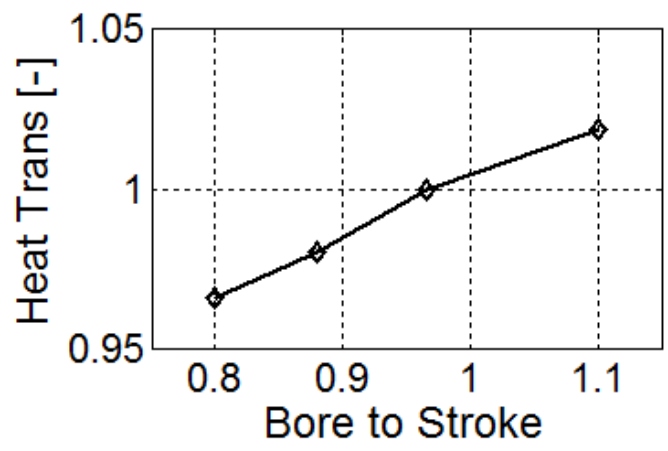

(a)

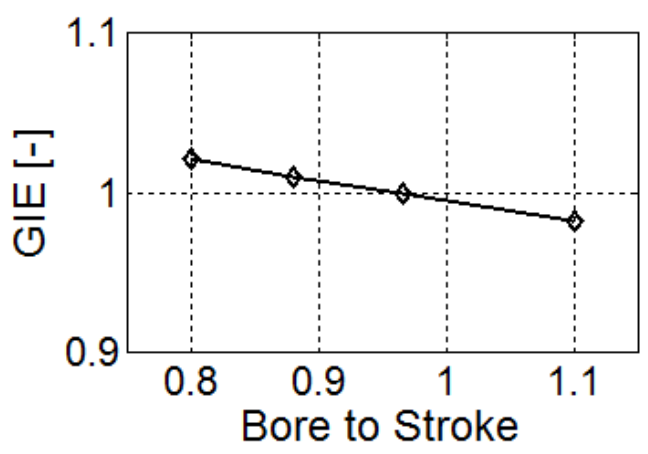

(b)

Figure 8 - Heat transfer (a) and Gross indicated efficiency (b) normalized by the reference B/S case at high-speed/load operating point.

Differences in heat transfer can be explained by the results presented in Figure 9. It is shown that despite lower $\mathrm{B} / \mathrm{S}$ ratios have higher wall heat transfer (HT) per surface area, probably due to faster HRL, but noticeably lower surface wall area. As expected this is the parameter that affects the most the heat losses when modifying $\mathrm{B} / \mathrm{S}$ ratio.

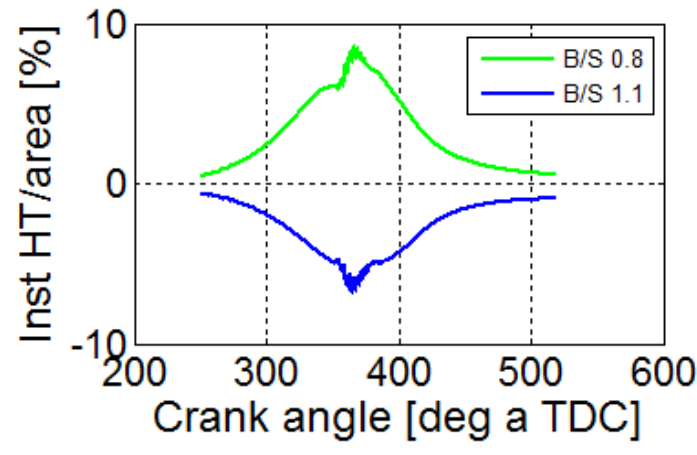

(a)

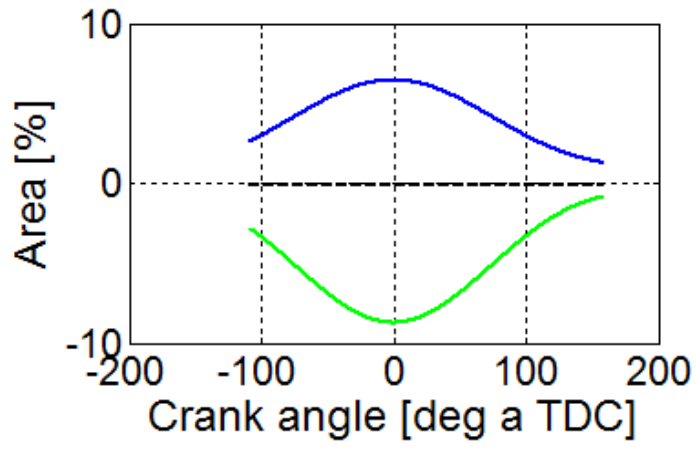

(b)

Figure 9 - Wall heat transfer per surface area (a) and total surface wall area (b) at highspeed/load operating point.

In addition to combustion and efficiency, pollutants are also affected by different $\mathrm{B} / \mathrm{S}$ ratios, as presented in Figure 10. Lower $\mathrm{B} / \mathrm{S}$ ratios produce higher NOx and lower soot emissions. The relative variations are higher for soot than for NOx, especially when $\mathrm{B} / \mathrm{S}$ increases. 


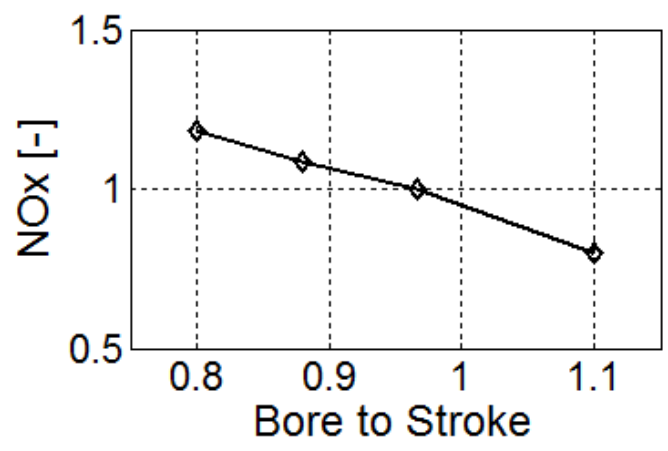

(a)

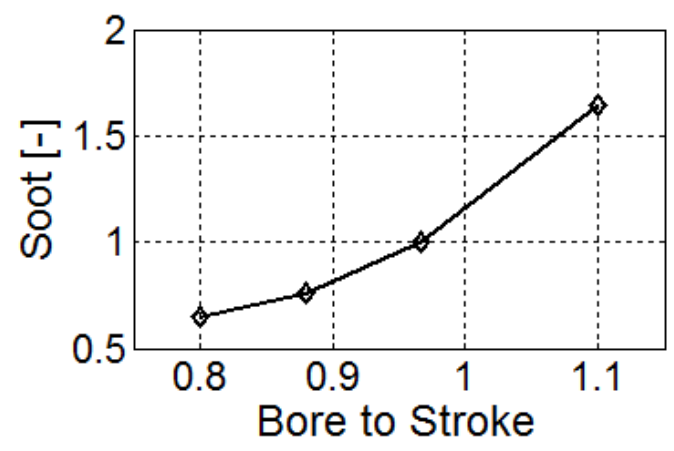

(b)

Figure 10 - NOx (a) and soot (b) normalized by the reference B/S case at high-speed/load operating point.

Focusing on NOx emissions, it could be expected from previous results that better mixing leads to faster combustion and higher in-cylinder temperatures. In particular, Figure 11 shows that for lower B/S the amount of mass with high temperature and lean conditions increases, and consequently [16], the NOx formation.

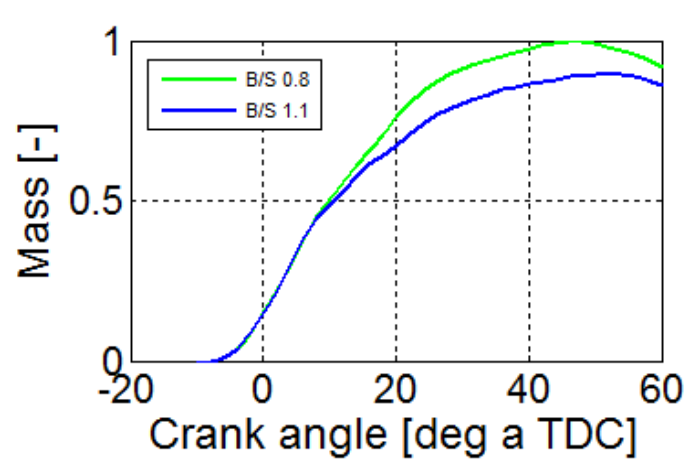

(a)

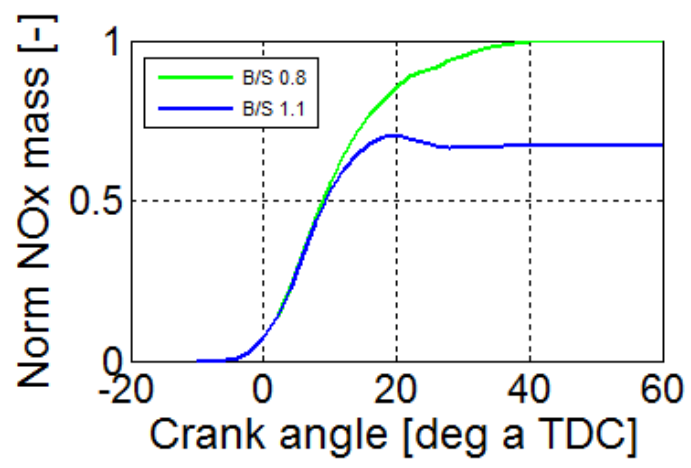

(b)

Figure 11 - In-cylinder mass with temperature over $1700 \mathrm{~K}$ and $\phi<1$ (a) and NOx mass normalized by the max. value (b) at high-speed/load operating point.

Regarding soot emissions, the general trend plotted in Figure 12 (a) shows that lower B/S ratios generate lower soot but also that there is a big difference between the formation and oxidation stages. The main difference in soot mass is generated during the formation stage, between 0 and 25 cad, the difference for 0.8 and $1.1 \mathrm{~B} / \mathrm{S}$ ratios is almost $50 \%$ of the maximum soot value. However, during the oxidation stage that difference is reduced to around $15 \%$. This is, the difference in soot formation cannot be compensated by the oxidation stage where higher $\mathrm{B} / \mathrm{S}$ ratios have a higher oxidation rate, so the main difference in the final soot emissions comes from the formation stage. 


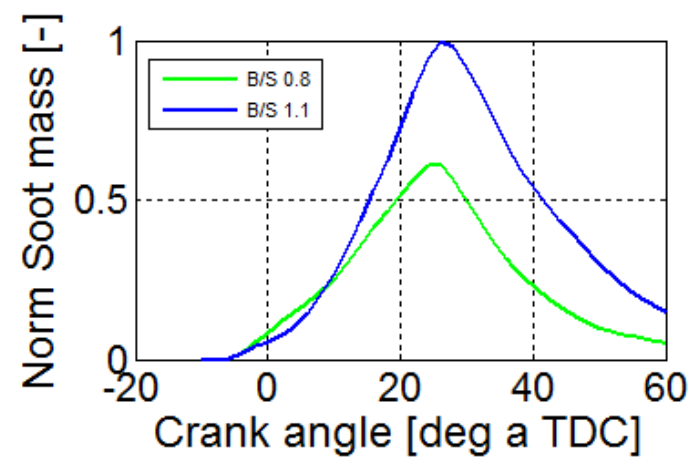

Figure 12 - Soot mass (normalized by the max. value) at high-speed/load operating point.

Soot formation rate is affected by mass with high temperatures and rich equivalence ratio. Then, Figure 13 shows the mass with equivalence ratio over two and high temperature within bowl and squish regions, to better locate the main difference in soot formation. It can be seen that there the main differences between $\mathrm{B} / \mathrm{S}$ ratios takes place within squish region, where the lower $\mathrm{B} / \mathrm{S}$ ratio has less rich and high temperature mass throughout the combustion process. Also Figure 13 (b) shows that the difference in rich mass generates nearly a $50 \%$ increase of peak soot mass within the squish region, being the main source for the soot variations for different $\mathrm{B} / \mathrm{S}$ ratios.

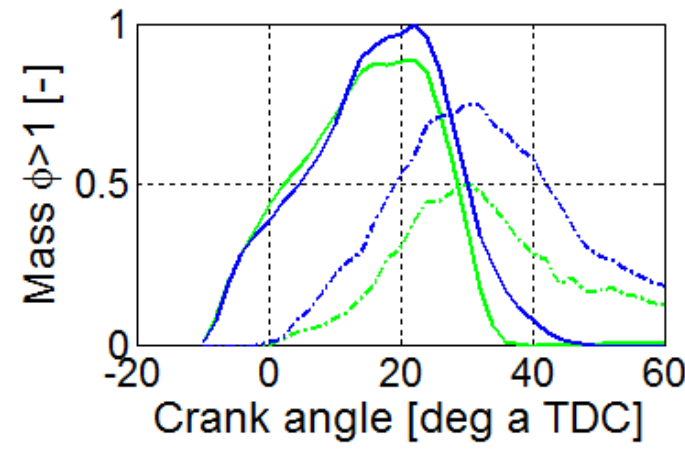

(a)

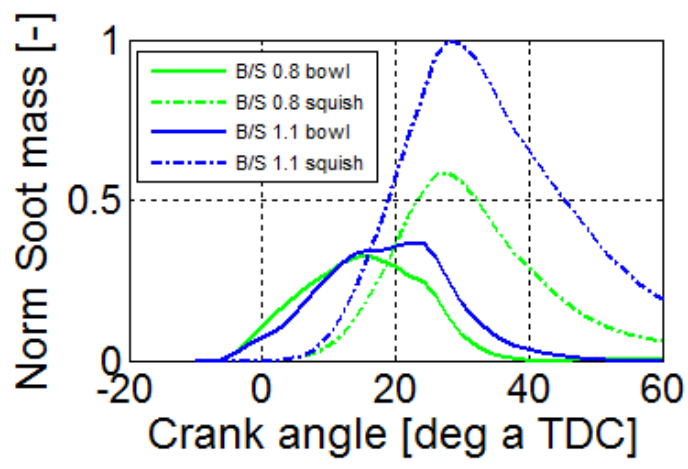

(b)

Figure 13 - Mass-averaged with $\Phi>1$ (a) and soot mass (b) in squish and bowl regions at highspeed/load operating point.

\subsection{B/S impact at different operating conditions}

In order to give a wider view of the effect of B/S ratio, the results obtained for both fulland part-load operating points with different B/S ratios are presented in this sub-section. All the plots show the values normalized by the reference $B / S$ ratio in order to facilitate the comparison.

Figure 14 shows how the combustion duration is shortened for lower B/S ratios for fullload conditions both peak torque (low-speed) and power (high-speed). This effect has not been found for the part-load point, which has shorter injection duration and also lower 
global equivalence ratio, and it is less sensitive to the $\mathrm{B} / \mathrm{S}$ ratio variations in terms of combustion duration.

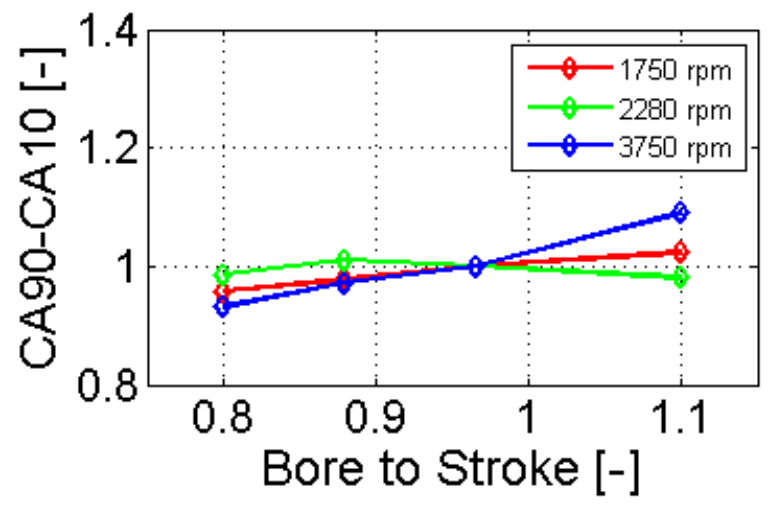

Figure 14 - Normalized combustion length for all the operating conditions of the engine.

The heat losses and GIE are plotted in Figure 15 for all the operating points. The general trends are kept for all operating conditions: lower B/S ratios results in lower heat losses and increased high-pressure cycle indicated efficiency. For part-load condition the improvement comes basically from decreased heat losses, while for full load cases is due to both reduced heat losses and combustion duration. The results and trends obtained in CFD calculations are in close agreement with test bench results from [12], where higher IMEP and then indicated efficiencies were obtained for the $\mathrm{B} / \mathrm{S}=0.85$ engine, which was the smaller B/S tested.

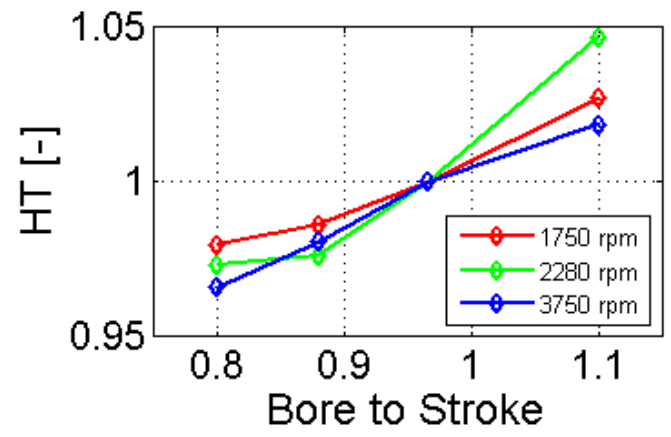

(a)

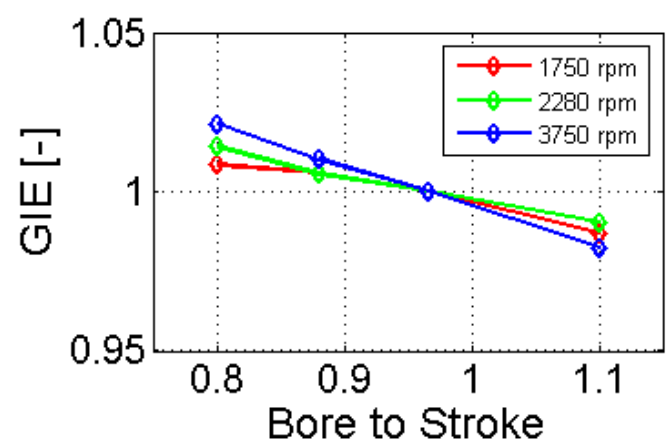

(b)

Figure 15 - Heat transfer losses (a) and GIE (b) for all operating conditions normalized by the value of the reference $B / S$ ratio for each operating condition.

Figure 16 compares the NOx and soot emissions for the different operating points. The same trends as those observed for the high-speed/load point can be also observes for the other operating conditions: NOx increases with lower B/S ratios and soot emissions are increased for higher $\mathrm{B} / \mathrm{S}$ ratios. 


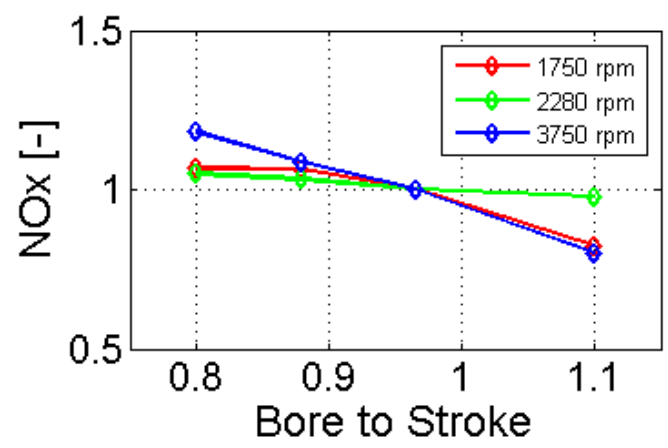

(a)

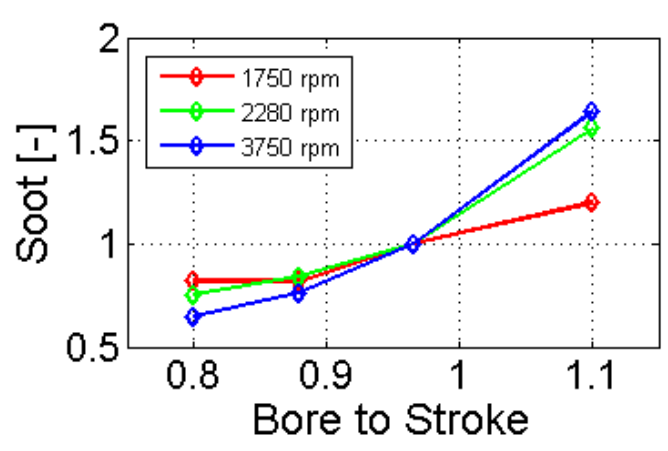

(b)

Figure 16 - NOx (a) and soot (b) for all operating conditions normalized by the value of the reference $B / S$ ratio for each operating condition.

The impact of B/S in NOx emissions is lower for the part load case. That case is the only case with EGR meaning that the temperatures during the combustion are lower than in any other case under high-load conditions. As it was said, the NOx formation ratio grows exponentially with temperature, but due to the lower in-cylinder temperatures of the part load case, as seen in Figure 17, the increase in temperature due to different B/S ratios has a lower impact. This results in a more favorable NOx-soot trade-off for part-load conditions when using lower B/S configurations, also found in [12].

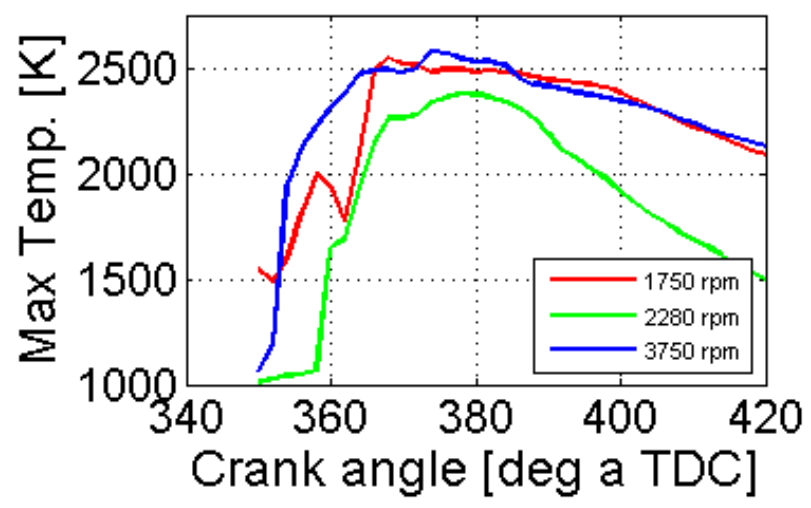

Figure 17 - In-cylinder max temperature for all operation conditions.

\section{Conclusions}

A CFD study of the impact of different bore-to-stroke configurations on HSDI CI engine efficiency and pollutants has been performed. Air management, injection settings and compression ratio have kept constant in order to isolate the effect of the $\mathrm{B} / \mathrm{S}$. The $\mathrm{B} / \mathrm{S}$ ratio study has been performed for three different operating conditions of the same engine (full-torque, full-power and one part-load).

The GIE proved to be noticeably affected by the B/S ratio. Lower bore-to-stroke setup ended with higher efficiencies mainly because of having lower heat transfer losses and faster combustion. Despite the heat transfer per unit area was higher for lower B/S due to 
better mixing and then faster combustion, the surface area (larger for high $\mathrm{B} / \mathrm{S}$ values) turned out to be the main reason for the differences in heat transfer.

The NOx emissions presented a strong dependence on the $\mathrm{B} / \mathrm{S}$ ratio, lower $\mathrm{B} / \mathrm{S}$ ratios generated higher NOx emissions. This trend was generated mainly because of the better mixing for lower B/S ratio configurations that ended up having higher amount of low equivalence ratio mass with high temperatures compared to the higher $\mathrm{B} / \mathrm{S}$ ratio cases.

The soot emissions showed a substantial dependence on the B/S ratio as well, lower B/S ratio generated lower soot emissions. The main soot generation difference was located in the squish region where the soot mass formed in the $0.8 \mathrm{~B} / \mathrm{S}$ ratio case was almost $50 \%$ of the soot mass formed in the $1.1 \mathrm{~B} / \mathrm{S}$ ratio case. That variation is coherent with the noticeable difference in rich mass with high temperature trapped in the squish region generated by the distinction in mixing.

The efficiency and emissions trends exposed for the high-speed/load (peak power) case were proven to be general for other operating conditions of the studied engine. It has to be highlighted that for part load conditions the trends were kept but the absolute effect of the $\mathrm{B} / \mathrm{S}$ ratio on the NOx emissions was almost negligible due to the lower average temperature in the combustion process. This results in a more favorable NOx-soot tradeoff when using lower B/S configurations.

\section{Acknowledgments}

Authors acknowledge that this work was possible thanks to the Ayuda para la Formación de Profesorado Universitario (FPU 13/02817) belonging to the Subprogramas de Formación y de Movilidad del Ministerio de Educación, Cultura y Deporte from Spain. 


\section{References}

1. ZAMBONI, G.; MOGGIA, S.; CAPOBIANCO, M. Hybrid EGR and turbocharging systems control for low NOX and fuel consumption in an automotive diesel engine. Applied Energy, 2016, vol. 165, p. 839-848.

2. POORGHASEMI,K.;Saray, R. K.;Ansari, E.; Irdmousa, B.K.; Shahbakhti, M.; Naber, J.D.. Effect of diesel injection strategies on natural gas/diesel RCCI combustion characteristics in a light duty diesel engine. Applied Energy, 2017, vol. 199, p. 430-446.

3. BENAJES, J.; NOVELLA, R.; PASTOR, J. M.; HERNÁNDEZ-LÓPEZ, A.; HASEGAWA, M.; TSUJI, N.; EMI, M.; UEHARA, I.; MARTORELL, J.; ALONSO, M. Optimization of the combustion system of a medium duty direct injection diesel engine by combining CFD modeling with experimental validation. Energy Conversion and Management, 2016, vol. 110, p. 212-229.

4. SHI, Y.; REITZ, R. D. Assessment of optimization methodologies to study the effects of bowl geometry, spray targeting and swirl ratio for a heavy-duty diesel engine operated at high-load. SAE International Journal of Engines, 2008, vol. 1, no 2008-01-0949, p. 537-557.

5. GE, H. W.; SHI, Y.; REITZ, R. D.; WICKMAN, D. D.; WILLEMS, W. Optimization of a HSDI diesel engine for passenger cars using a multi-objective genetic algorithm and multi-dimensional modeling. SAE International Journal of Engines, 2009, vol. 2, no 2009-01-0715, p. 691-713.

6. PEDROZO, V.B.; MAY, I.; DALLA N.M.; CAIRNS, A.; ZHAO, H. Experimental analysis of ethanol dual-fuel combustion in a heavy-duty diesel engine: An optimization at low load. Applied Energy, 2016, vol. 165, p. 166-182.

7. BEATRICE, C.; NAPOLITANO, P.; GUIDO, C. Injection parameter optimization by DoE of a lightduty diesel engine fed by Bio-ethanol/RME/diesel blend. Applied Energy, 2014, vol. 113, p. 373-384.

8. MILES, P.C.; ANDERSSON, Ö. A review of design considerations for light-duty diesel combustion systems. International Journal of Engine Research, 2016, vol. 17, no 1, p. 6-15.

9. GENZALE, C. L.; REITZ, R. D.; MUSCULUS, M. PB. Effects of piston bowl geometry on mixture development and late-injection low-temperature combustion in a heavy-duty diesel engine. SAE Technical Paper, 2008.

10. BENAJES, J.; PASTOR, J.V.; GARCÍA, A.; MONSALVE-SERRANO, J. An experimental investigation on the influence of piston bowl geometry on RCCI performance and emissions in a heavyduty engine. Energy Conversion and Management, 2015, vol. 103, p. 1019-1030.

11. CHOI, S.; SHIN, S.; LEE, J.; MIN, K.; CHOI, H. The effects of the combustion chamber geometry and a double-row nozzle on the diesel engine emissions. Proc Inst Mech Eng, Part D: J Automobile Eng 2015; 229(5):590-8.

12. KERMANI, J.; DE PAOLA, G.; KNOP, V.; GARSI, C.; RUHLAND, H.; WILLEMS, W.; KAUDEWITZ, T.; MORK, A. An Experimental Investigation of the Effect of Bore-to-Stroke Ratio on a Diesel Engine. SAE Technical Paper, 2013.

13. FASOLO, B.; DOISY, A.; DUPONT, A; LAVOISIER, F. Combustion System Optimization of a New 2 Liter Diesel Engine For EURO IV. SAE Technical Paper 2005-01-0652, 2005

14. VASSALLO, A.; GOPALAKRISHNAN, V.; ARRIGONI, S.; CAVALLO, R.; TURCATO, R.; RACCA, A. Impact of Bore-to-Stroke Ratio Over Light-Duty DI Diesel Engine Performance, Emissions and Fuel Consumption: An Analytical Study Using 1D-CFD Coupled with DOE Methodology. SAE Technical Paper, 2013.

15. LEE, C.; GOEL, S.; BABAJIMOPOULOS, A. The effects of stroke-to-bore ratio on HCCI combustion. SAE Technical Paper, 2010.

16. HEYWOOD, J. B. Internal combustion engine fundamentals. New York: Mcgraw-Hill, 1988.

17. PAYRI, F.; OLMEDA, P.; MARTIN, J.; CARREÑO, R. A new tool to perform global energy balances in DI diesel engines. SAE International Journal of Engines, 2014, vol. 7, no 1, p. 43-59.

18. PAYRI, F.; OLMEDA, P.; MARTIN, J.; CARREÑO, R. Experimental analysis of the global energy balance in a DI diesel engine. Applied Thermal Engineering, 2015, vol. 89, p. 545-557.

19. LAPUERTA, M.; ARMAS, O.; HERNÁNDEZ, J. J. Diagnosis of DI Diesel combustion from incylinder pressure signal by estimation of mean thermodynamic properties of the gas. Applied Thermal Engineering, 1999, vol. 19, no 5, p. 513-529.

20. PAYRI, F.; MOLINA, S.; MARTÍN, J.; ARMAS, O. Influence of measurement errors and estimated parameters on combustion diagnosis. Applied Thermal Engineering, 2006, vol. 26, no 2, p. 226-236. 
21. SUBRAMANIAN, G.; VERVISCH, L.; RAVET, F. New developments in turbulent combustion modeling for engine design: ECFM-CLEH combustion submodel. SAE Technical Paper, 2007.

22. ABOURI, D.; ZELLAT, M.; DURANTI, S.; RAVET, F. Advances in combustion modeling in STARCD: validation of ECFM- CLEH model to engine analysis. $18^{\text {th }}$ International Mutidimentional Engine User's Meeting at the SAE congress. 2008.

23. VERVISCH, P.E.; COLIN O.; MICHEL, J.-B.; DARABIHA N. NO Relaxation Approach (NORA) to predict thermal NO in combustion chambers. Combustion and Flame, 2011, vol. 158(8), p. 1480-1490.

24. MARCHAL, C. Modélisation de la formation et de l'oxydation des suies dans un moteur automobile. 2008, PhD Thesis. Université d'Orléans.

25. DUKOWICZ J. A particle fluid numerical model for liquid sprays. J Comput Phys, 1980, Vol. 35, p. 229-253.

26. HUH, K. Y.; GOSMAN, A. D. A phenomenological model of diesel spray atomization. In Proceedings of the international conference on multiphase flows. 1991.

27. REITZ, R. D.; DIWAKAR, R. Structure of high-pressure fuel sprays. SAE Technical Paper, 1987.

28. HABCHI, C,; LAFISSAS, F. A.; BÉARD, P.; BROSETA, D. Formulation of a one-component fuel lumping model to assess the effects of fuel thermodynamic properties on internal combustion engine mixture preparation and combustion. SAE Technical Paper, 2004.

29. YAKHOT, V.; ORSZAG, S. A. Renormalization group analysis of turbulence. I. Basic theory. Journal of scientific computing, 1986, vol. 1, no 1, p. 3-51.

30. ANGELBERGER, C.; POINSOT, T.; DELHAY, B. Improving near-wall combustion and wall heat transfer modeling in SI engine computations. SAE Technical Paper, 1997.

31. ISSA, R. I. Solution of the implicitly discretised fluid flow equations by operator-splitting. Journal of computational physics, 1986, vol. 62, no 1, p. 40-65.

32. LUCCHINI, T.; DELlA TORRE, A.; D'ERRICO, G.; MONTENEGRO et al. Automatic Mesh Generation for CFD Simulations of Direct-Injection Engines. SAE Technical Paper 2015-01-0376, 2015.

33. BENAJES, J.; MARTÍN, J.; GARCÍA, A.; VILLALTA, D.; WAREY, A. In-cylinder soot radiation heat transfer in direct-injection diesel engines. Energy Conversion and Management, 2015, vol. 106, p. 414-427. 
NOMENCLATURE

$\begin{array}{ll}\text { aTDC } & \text { After Top Dead Center } \\ \text { BDC } & \text { Bottom Dead Center } \\ \text { B/S } & \text { Bore-to-stroke } \\ \text { CA90 } & \text { Crank angle for 90\% of fuel burnt } \\ \text { CI } & \text { Compression Ignition } \\ \text { CFD } & \text { Computational Fluid Dynamics } \\ \text { DI } & \text { Direct Injection } \\ \text { EGR } & \text { Exhaust Gas Recirculation } \\ \text { EVO } & \text { Exhaust Valve Opening (angle) } \\ \text { EXP } & \text { Experimental } \\ \text { HRR } & \text { Heat Release Rate } \\ \text { HRL } & \text { Accumulated heat release law } \\ \text { ICE } & \text { Internal Combustion Engines } \\ \text { IMEP } & \text { Indicated Mean Effective Pressure } \\ \text { IVC } & \text { Intake Valve Closing (angle) } \\ \text { m }_{\text {IVC }} & \text { In-cylinder mass at IVC } \\ \text { P }_{\text {IVC }} & \text { Pressure at IVC } \\ \text { TDC } & \text { Top Dead Centre } \\ T_{\text {IVC }} & \text { Temperature at IVC } \\ \text { Y }_{\text {O2 }} & \text { In-cylinder oxygen concentration } \\ \text { Y }_{\text {N2 }} & \text { In-cylinder nitrogen concentration } \\ \text { Y }_{\text {RES }} & \text { In-cylinder residuals concentration }\end{array}$

